Fertility and sterility in bacterial cells may thus be nothing more than an epiphenomenon of their surface charges; on the other hand, the observed differences of surface charge may be a minor effect of the $F$ agent which is supposed to transmit fertility. Our results make the first hypothesis no more unreasonable than the second one.

G. A. Maccacaro

Istituto di Patologia Generale,

Università di Milano.

Feb. 25 .

${ }^{1}$ Lederberg, J., Cavalli, L. L., and Lederberg, E. M., Genetics, 37, 720 (1952).

2 Cavalli, L. L., Lederberg, J., and Leđerberg, E. M., J. Gen. Microbiol. $8,89(1953)$

-Tolstoouhov, A. V., Stain Tech., 4, 83 (1929).

4 Houwink, A. L., and Van Iterson, W., Biochim. Biophys. Acta, 5, 10 (1950).

s Brinton, C. C., Buzzell, A., and Lauffer, M. A., Biochim. Biophys. Acta, 15, 533 (1954).

\section{Herpetichthyes, Amphibioidei, Choanichthyes or Sarcopterygii?}

DURING recent decades, our ideas on the classification of fishes have changed greatly. In the early years of the century, it was believed that among the higher bony fishes (Osteichthyes), the ray-finned forms and crossopterygians were closely allied, and that the lungfishes were remote from the two, representing a presumably primitive if aberrant group. As an expression of such beliefs may be cited Goodrich's work on fishes in the Lankester "Treatise on Zoology"1, in which the Osteichthyes are divided into two subclasses, one for the Dipnoi alone, the other, the Teleostomi, including both Crossopterygii and the Actinopterygii. In succeeding decades, however, a radical change of opinion occurred. Principelly due to the work of Goodrich himself and of Gregory and Watson, it became clear that the primary dichotomy of the Osteichthyes was of another sort, one major subdivision including the Actinopterygii alone, the other both Crossopterygii and Dipnoi. Huxley, in $1880^{2}$, coined the name Herpetichthyes to describe the sub-tetrapod evolutionary stage represented by Ceratodus, and Smith Woodward, in $1931^{8}$, suggested the expansion of the term to include (contra Huxley) the crossopterygians. Hubbs, in $1919^{4}$, proposed Amphibioidei for Dipnoi plus Crossopterygii, and other writers have suggested an expansion of Crossopterygii to include the Dipnoi as well. Säve-Söderbergh, in $1934^{5}$, in an unorthodox essay in classification, proposed a major subdivision of the vertebrates, including all the tetrapod classes plus the two fish groups concerned, to be named the Choanata, in reference to the presence of internal nostrils. I have (like others) rejected this classification, but in $1937^{6}$ suggested that Choanichthyes would be appropriate as a designation for the included fish groups. None of the three terms previously suggested has met with any marked degree of acceptance; Choanichthyes has been adopted by a number of recent writers.

The deadening hand of legal 'priority' fortunately does not (and should not) extend to systematic categories on this high level. Names of this sort should be meaningful and, if possible, diagnosticparticularly in such a group as that under consideration, which is of such importance that it merits mention and discussion on even the most elementary levels of zoological and geological teaching. From this point of view, I feel dubious as to whether the term Choanichthyes should be retained. The lungfishes have internal narial openings, to be sure, and it seems certain that the crossopterygian ancestors of the tetrapods had choanæ. But in coelacanths, choanæ were lost at a very early stage, if ever present at all. The internal narial openings of the lungfish do not function as choanæ, for they are passages for water, not air, and Jarvik ${ }^{7}$, among others, has raised doubts as to their homology with true choanæ.

But despite my doubts about the use of the term Choanichthyes, no better case can be made for alternatives which have been proposed. As regards the use of Herpetichthyes or Amphibioidei, the fishes concerned are related to amphibian ancestry; but the only living member of the group, Latimeria, is as un-amphibian as any fish can be. To use Crossopterygii in the expanded sense proposed would distort the meaning of the term so greatly as to create confusion.

A name which is highly appropriate and didactically useful can, however, be derived from fin structure. In contrast to the typical Actinopterygii, all crossopterygians and lungfishes have fleshy, lobate fins, covered with scales and with a well-developed internal skeleton of archipterygial type. May I suggest, for discussion, the possibility that, in contrast to the 'ray-finned fishes', the forms here considered be termed 'fleshy-finned fishes'Sarcopterygii ?

\section{Alfred Sherwood Romer}

Museum of Comparative Zoology, Harvard University. Jan. 12.

"Goodrich, E. S., "Vertebrata Craniata", fasc. 1, in "A Treatise on Zoology", Part IX (edit. Sir Ray Lankester, London, 1909) ${ }^{2}$ Huxley, T. H., Proc. Zool. Soc. London, 1880, 600 (1881).

${ }^{3}$ Woodward, A. S., Imp. Coll. Sci. Tech., Huxley Memorial Lecture, 8 (1931).

4 Hubbs, C. L., Science, 49, 569 (1919)

' Säve-Söderbergh, G., Arkiv. för Zoologi, 26A, No, 17, 8 (1934).

- Romer, A. S., Bull. Mus. Comp. Zool., 82, 56 (1937).

'Jarvik, E., Zool. Bidrag Uppsala, 21, 280 (1942).

We are glad to see Prof. A. S. Romer's authority withdrawn from the unhappy term Choanichthyes; but we do not think it necessary or desirable to coin a new one to cover the Rhipidistia, Actinistia and Dipnoi. We would revert to calling them all Crossopterygii.

The name Crossopterygii in its original form (Crossopterygidae) was introduced by T. H. Huxley ${ }^{1}$ to include members of all of the above-named groups, as well as Polypterus, which to-day is excluded from the Crossopterygii in whatever sense the term is used. In Huxley's Crossopterygidae were Osteolepis, the Coelacanthidae, Dipterus, Phaneropleuron and the fossil Ceratodus (the last with a query, since it was known only from dental plates). Huxley further directed attention, "without wishing to lay too much stress upon the fact", to the resemblance between Lepidosiren, the only living dipnoan then known, and Dipterus, Phaneropleuron and the coelacanths, mentioning the paired fins and the endoskeleton and comparing the teeth with those of Dipterus and the "stiff-walled lung" with the ossified air bladder of one of the fossil coelacanths.

In 1881, in the work referred to by Prof. Romer, Huxley was thinking as a comparative anatomist, and gave the name Herpetichthyes to Ceratodus (=Neoceratodus) and its hypothetical ancestors. 